\title{
Membrane Biofouling of Seawater Reverse Osmosis Initiated by Sporogenic Bacillus Strain
}

\author{
Jinwook Lee ${ }^{1}$, Xianghao Ren ${ }^{2}$, Hye-Weon $\mathrm{Yu}^{3}$, Sung-Jo Kim ${ }^{3}$, In S. Kim ${ }^{1,3 \dagger}$ \\ ${ }^{1}$ Center for Seawater Desalination Plant, Gwangju Institute of Science and Technology, Gwangju 500-712, Korea \\ ${ }^{2}$ Key Laboratory of Urban Stormwater System and Water Environment, School of Environment and Energy Engineering, \\ Beijing Univer sity of Civil Engineering and Architecture, Beijing 100-044, China \\ ${ }^{3}$ Department of Environmental Science and Engineering, Gwangju Institute of Science and Technology, Gwangju 500-712, Korea
}

\begin{abstract}
The objective of this study was to assess the biofouling characteristics of the Bacillus biofilm formed on reverse osmosis (RO) membranes. For the study, a sporogenic Bacillus $s p$. was isolated from the seawater intake to a RO process, with two distinct sets of experiments performed to grow the Bacillus biofilm on the RO membrane using a lab-scale crossflow membrane test unit. Two operational feds were used, $9 \mathrm{~L}$ sterile-filtered seawater and $10^{9}$ Bacillus cells, with flow rates of $1 \mathrm{~L} / \mathrm{min}$, and a constant 800 psi-pressure and pH 7.6 . From the results, the membrane with more fouling, in which the observed permeate flux decreased to $33 \%$ of its initial value, showed about 10 and 100 times greater extracellular polymeric substances and spoOA genes expressions, respectively, than the those of the less fouled membrane (flux declined to $20 \%$ of its initial value). Interestingly; however, the number of culturable Bacillus sp. in the more fouled membrane was about 10 times less than that of the less fouled membrane. This indicated that while the number of Bacillus had less relevance with respect to the extent of biofouling, the activation of the genes of interest, which is initiative of biofilm development, had a more positive effect on biofouling than the mass of an individual Bacillus bacterium.
\end{abstract}

Keywords: Bacillus sp., Biofilm, Gene expression, Extracellular polymeric substance, Reverse osmosis membrane, spoOA

\section{Introduction}

Due to the acceleration of global warming and the stress that population growth has placed on the global water supply, the desalination of seawater via reverse osmosis (RO) has shown promise as a technology for overcoming the stress on water resources. However, membrane fouling is a common problem, as it causes flux decline, demands frequent cleaning and consumes a large amount of energy, resulting in a shortened lifespan of the system [1]. Among the types of fouling material, severe biofilm formation by variable bacteria, called biofouling, is the most difficult to control. It was reported that 58 of $70 \mathrm{RO}$ membrane and about $70 \%$ of the seawater RO membrane installations surveyed in U.S. suffered from biofouling problems [2, 3]. To avoid or reduce the biofouling on the membrane, a deeper understanding of uncontrollable biofouling is critical.

In an attempt to address this issue, a number of studies have focused on measuring the densities of biological matter [4]. About $1 \times 10^{7}$ cells per $\mathrm{cm}^{2}$ of fouled RO membrane surface was observed, with bacteria, such as Pseudomonas, Corynebacterium, Bacillus, Arthrobacter, Flavobacter, Mycobacterium, Acineto- bacter and Cytophaga-Flavobacter-Bacteroidetes group found to participate in biofilm development on RO membranes [5, 6]. However, the selection of the most predominant and problematic microorganism is not simple since the dominance of bacterial species varies from one to facility to another depending on site-specific conditions, such as feed water quality, temperature, location and the processes involved. Accordingly, due to the diversity of predominant bacteria, a model biofilm associated strains or bacterial isolates retrieved from the fouled RO membrane are used in biofouling studies. For example, Pseudomonas strains have frequently been studied as primary biofouling microorganisms in the RO process for wastewater treatment $[7,8]$. However, the Pseudomonas and RO membranes in these studies have not been employed for seawater treatment.

Bacillus $s p$. strains, or its relatives, have also arisen as problematic bacteria as they are commonly observed in different biofilm community structures on $\mathrm{RO} / \mathrm{NF}$ membranes used for water treatment [9-12]. The higher hydrophobicity of Bacillus $s p$. Over that of Pseudomonas enhances the cell adhesion onto RO membranes [13].

Based on our previous studies, the approach using Bacillus (c) This is an Open Access article distributed under the terms of the Creative Commons Attribution Non-Commercial License (http://creativecommons. org/licenses/by-nc/3.0/) which permits unrestricted non-commercial use, distribution, and reproduction in any medium, provided the original work is properly cited.
Received March 03, 2010 Accepted June 24, 2010

${ }^{\dagger}$ Corresponding Author

E-mail: iskim@gist.ac.kr

Tel: +82-62-715-3381 Fax: +82-62-715-2434 
biofilm formation in a crossflow membrane test unit for seawater RO, as well as the $s p o O A$ gene expression assay of Bacillus biofilm, have rarely been reported. The $s p o O A$ gene is known as a sporulation transcription factor and its production is required by Bacillus cells to enter the biofilm developmental process [14]. Thus, the measurement of spoOA gene expression is assumed to be a biofouling indicator. The objective of this study was to diagnose the seawater RO biofouling induced by a Bacillus strain. When Bacillus adhesion and growth were allowed to occur in two different RO systems with feed seawater, the relevance between the number of Bacillus and the extent of biofouling was assessed. For biofouling measurements, not only typical biomass accumulation parameters, but a specific gene expression assay was performed.

\section{Materials and Methods}

\subsection{Characteristics of Seawater Sample}

The seawater was sampled from what will be the intake to a seawater reverse osmosis (SWRO) desalination plant (longitude $35^{\circ} 13^{\prime} 32 \mathrm{~N}$; latitude $129^{\circ} 14^{\prime} 37 \mathrm{~N}$ ) due to be constructed in 2011 in Korea through the seaHERO R\&D program supported by the Ministry of Land, Transport and Maritime Affairs [15]. Water was taken from 7 meters below sea level. The seawater quality data, regularly acquired in 2008 and 2009, are presented in Table 1, and were observed to be fairly consistent. It should be noted that the cell densities in the collected samples were not relatively high compared to those observed in other studies; for example,

Table 1. Composition of the seawater feed used in this study

\begin{tabular}{|c|c|}
\hline Water quality parameter (unit) & Average measurement (stdev) \\
\hline Total count (cells $/ \mathrm{mL}$ ) & $4.12 \mathrm{E}+5 \sim 8.35 \mathrm{E}+5$ \\
\hline $\mathrm{pH}$ & $7.66(0.28)$ \\
\hline Turbidity (NTU) & $0.51(0.17)$ \\
\hline TSS (mg/L) & $19.94(2.09)$ \\
\hline TDS (mg/L) & $36,642.60(2,456.10)$ \\
\hline TOC (mg/L) & $2.42(0.89)$ \\
\hline $\mathrm{Na}^{+}(\mathrm{mg} / \mathrm{L})$ & $11,070.20(1,497.63)$ \\
\hline $\mathrm{K}^{+}(\mathrm{mg} / \mathrm{L})$ & $434.80(35.31)$ \\
\hline $\mathrm{Mg}^{2+}(\mathrm{mg} / \mathrm{L})$ & $1,346.80(134.39)$ \\
\hline $\mathrm{Ca}^{2+}(\mathrm{mg} / \mathrm{L})$ & $569.94(114.65)$ \\
\hline $\mathrm{NO}_{3}^{-}(\mathrm{mg} / \mathrm{L})$ & $0.01(0.02)$ \\
\hline $\mathrm{NH}_{4}{ }^{+}(\mathrm{mg} / \mathrm{L})$ & $0.01(0.03)$ \\
\hline $\mathrm{HCO}_{3}^{-}(\mathrm{mg} / \mathrm{L})$ & $2,426.80(32.09)$ \\
\hline $\mathrm{Cl}^{-}(\mathrm{mg} / \mathrm{L})$ & $18,876.80(1,541.59)$ \\
\hline $\mathrm{SO}_{4}{ }^{2-}(\mathrm{mg} / \mathrm{L})$ & $2,740.80(463.66)$ \\
\hline $\mathrm{B}(\mathrm{mg} / \mathrm{L})$ & $4.23(0.33)$ \\
\hline $\mathrm{Si}(\mathrm{mg} / \mathrm{L})$ & $0.22(0.11)$ \\
\hline $\mathrm{Fe}(\mathrm{mg} / \mathrm{L})$ & $0.08(0.05)$ \\
\hline $\mathrm{Zn}(\mathrm{mg} / \mathrm{L})$ & $0.02(0.03)$ \\
\hline $\mathrm{Sr}(\mathrm{mg} / \mathrm{L})$ & $6.75(0.07)$ \\
\hline
\end{tabular}

bacterial cells in the northern Gulf of Mexico ranged from $0.4 \times$ $10^{6}$ cells $/ \mathrm{mL}$ offshore to $1.0 \times 10^{6}$ cells $/ \mathrm{mL}$ inshore [16] .

An untreated seawater sample was used for the isolation of bacteria, including sporogenous Bacillus strains, with sterile micro filtered seawater used as the feed solution for the formation of the biofilm in a lab-scale crossflow membrane test unit.

\subsection{Isolation of Bacillus sp. from the Seawater Sample and Sequencing}

For the isolation of the bacteria from the seawater sample, the following membrane filtration technique was used. After filtering through a $0.45 \mu \mathrm{m}$ pore-size cellulose acetate membrane, the cells remaining on the filter were transferred to a marine agar plate (Difco 2216) and incubated at $37^{\circ} \mathrm{C}$ until individual colonies were grown. Each colony was then genetically identified by sequencing of the amplified 16S rRNA gene. For amplification, a universal bacterial primer set, forward primer 9F (5'-GAG TTT GAT CCT GGC TCA G-3') and reverse primer 1512R (5'-ACG GHT ACC TTG TTA CGA CTT-3') was used [12]. In total, 37 strains were purified, with 7 of these isolates deemed to be close to Bacillus $s p$., as their sequence homologies were more than $99 \%$; Ten sequence sources of the representative bacteria belonging to the phylum-based bacterial group were then registered in Genbank (Genbank accession no. FJ869031-FJ869040; Table 2). Finally, the Bacillus sp. Sea-3 (FJ869033) culture, due to its specificity with respect to color and colony morphology, was used to investigate the biofilm formation on an RO membrane.

\subsection{Operation of RO Membrane Module and Biofilm Formation on RO Membrane}

Two distinct sets of experiments were performed, based on fouling protocols, using a lab-scale crossflow membrane test unit (Sepa CF II; GE Osmonics, Minnetonka, MN, USA). The fouling protocols can be roughly summarized into two main categories. One being a disinfecting RO test unit before applying the fouling protocol (Case I), with the other being an omitting disinfection of an RO test unit (Case II). For the Case I experiment, the lab-scale crossflow membrane test unit was disin-

Table 2. NCBI accession numbers of the bacteria isolated from seawater

\begin{tabular}{lcc}
\hline $\begin{array}{l}\text { Microorganism } \\
\text { (based on 16S ribosomal RNA gene) }\end{array}$ & $\begin{array}{c}\text { Sequence } \\
\text { length } \\
\text { (bp) }\end{array}$ & $\begin{array}{c}\text { NCBI } \\
\text { accession } \\
\text { number }\end{array}$ \\
\hline Roseobacter sp. Sea-1 & 1198 & FJ869031 \\
Tenacibaculum discolor strain Sea-2 & 1235 & FJ869032 \\
Bacillus sp. Sea-3 & 1264 & FJ869033 \\
Bacillus sp. Sea-4 & 1287 & FJ869034 \\
Pseudomonas marincola strain Sea-5 & 1213 & FJ869035 \\
Bacillus oshimensis strain Sea-7 & 1243 & FJ869036 \\
Bacillus horikoshii strain Sea-9 & 793 & FJ869037 \\
Burkholderia sp. Sea-8 & 784 & FJ869038 \\
Bacillus lehensis strain Sea-10 & 784 & FJ869039 \\
Microbacterium sp. Sea-11 & 750 & FJ869040
\end{tabular}

NCBI: National Center for Biotechnology Information. 
fected with $0.5 \%$ sodium hypochlorite, $5 \mathrm{mM}$ ethylene diamine tetra acetate (EDTA), $2 \mathrm{mM}$ sodium dodecyl sulfate (SDS), $95 \%$ ethanol and deionized (DI) water [17] prior to the addition of the Bacillus foulants into sterilized seawater feed. In the second set of experiments (Case II), the test unit was cleaned with DI water only, with biofilm formation then carried out in the same manner as in Case I.

A flat sheet polyacrylamide RO membrane, having an effective area of $140 \mathrm{~cm}^{2}$, with a spacer, was placed in the test unit (part no. 1142819, GE Osmonics). The experiment was performed in a $20 \mathrm{~L}$ feed tank with a $9 \mathrm{~L}$ feedwater volume. The feedwater was composed of micro filtered, sterilized seawater dosed with $10^{9}$ cells of a Bacillus sp. Sea-3 isolate. During the 200-250 hours operation period, at a pressure of 800 psi and crossflow velocity of $1 \mathrm{~L} / \mathrm{min}$ at $20^{\circ} \mathrm{C}$, both the permeate and retentate were recirculated to the feed tank.

\subsection{Autopsy of Biofouled RO Membranes and SEM Ob- servation for the Surface of RO Membrane}

The RO membrane was retrieved from the test unit and cut into $10 \mathrm{~cm} \times 1 \mathrm{~cm}$ sized-pieces. Each piece was then placed in a $15 \mathrm{~mL}$ conical tube containing $10 \mathrm{~mL}$ of distilled sterile water. To analyze the microbiological and organic compounds based on criteria, such as dry weight, organic matter, protein and carbohydrate contents, each rectangular piece of RO membrane was sonicated for 10-15 minutes using a bath-type sonicator, as the biofilm microorganisms adhering to the surface of membranes were not sufficiently detached by scraping and vigorous stirring only.

For scanning electron microscope (SEM) observation, the fouled regions of the $\mathrm{RO}$ membranes were carefully cut into very small pieces of less than $1 \mathrm{~cm} \times 1 \mathrm{~cm}$. The SEM observation required pretreatment of the membrane sections. The membrane samples were fixed with a $2 \%$ glutaraldehyde solution for 1 hour at $4^{\circ} \mathrm{C}$, dried for 5 minutes at $35^{\circ} \mathrm{C}$, and subsequently serially dehydrated for 3 minutes in 50, 80 and 96\% EtOH solutions. After placing in a drying chamber overnight, the membrane samples were then coated with Pt for $35 \mathrm{~s}$ using ion sputtering (E-1030; Hitachi, Tokyo, Japan) prior to the SEM (S-4700; Hitachi) observation.

Note: the entire process of membrane autopsy and sampling was undertaken under aseptic conditions. All solutions were prepared with distilled water, autoclaved, and then filtered through a cellulose acetate membrane with a pore size of $0.2 \mu \mathrm{m}$. All storage receptacles and filtration membranes were sterile and disposable.

\subsection{Measurements of Total Bacteria Count, Bacillus sp. Count and Viability}

Direct measurements of total count and viability were carried out based on fluorescent staining. For the total count, 1 $\mathrm{mg} / \mathrm{mL} 4^{\prime}$-6-diamidino-2-phenylindole (DAPI) was applied to the biofilm extract sample for DNA staining, with the staining solution transferred to a $0.2 \mu \mathrm{m}$-pore sized black polycarbonate membrane for confocal laser scanning microscopy (CLSM) observation. Ten fluorescent images were randomly captured using a LSM5 (Zeiss, Oberkochen, Germany) inverted CLSM, linked to a PC, with LSM software (PASCAL, Oberkochen, Germany) used to control all the system components. A mercury lamp was used as the light source, and imaging was achieved us- ing a C-Apochromat $40 \times$ objective. A quantitative analysis of the fluorescent signal on the image captured from a LSM confocal microscope was then conducted using image analyzer software (isolution/Lite, $i$ MTechnology, Korea).

To determine the viability, a LIVE/DEAD BacLight staining kit (L-7012; Molecular Probes, USA) was used to enumerate the viable bacteria from the biofilm cells. The staining procedure followed the instructions provided by the manufacturer; application of the two different dyes resulted in green fluorescence, indicating viable cells, and red fluorescence for dead cells, due to SYTO 9 and PI, respectively. Finally, the viability (\% of viable cells) was obtained using a flow cytometer (Cell Lab Quanta SC; Beckman Coulter, USA).

Spread plate counting was used to enumerate the viable Bacillus $s p$. Sea- 3 cells from the biofilm extract. Here, $10 \mu \mathrm{L}$ of the biofilm extract was spread on marine agar plates, with the plates incubated at $37^{\circ} \mathrm{C}$ overnight. Bacillus $s p$. Sea- 3 was easily discriminated from the other species since it had orange-colored colonies. Twelve other colonies, with different colors and morphologies were identified using polymerase chain reaction (PCR)-amplified 16S rRNA genes; PCR-based 16S rRNA gene amplification and sequencing were undertaken in the same manner outlined above. All determinations were performed at least in triplicate.

\subsection{Measurements of EPS Proteins and EPS Hexose}

The biofilms extracted from the $10 \mathrm{~cm} \times 1 \mathrm{~cm}$ rectangular RO membrane pieces into $10 \mathrm{~mL}$ sterile water were stored in $15 \mathrm{~mL}$ conical tubes. Several of the conical tubes were then used to determine the dry weight, organic matter content and EPS hexose content [4]. Here, the EPS protein concentration was measured using a Micro BCA protein assay kit (Cat no. 23235; Thermo Scientific Pierce, USA), with EPS extract prepared from the biofilm extract [18].

\subsection{Measurement of spoOA Gene Expressions by RT-PCR}

DNA and RNA extractions from the biofilm cells were carried out, with the same volume of biofilm cells being used in each extraction. Genomic DNA was extracted using a phenol/ chloroform extraction and ethanol precipitation method. The extracted DNA was then quantified using a spectrophotometer (Ultraspec 3100pro, Amersham Pharmacia Biotech, Sweden) at $260 \mathrm{~nm}$. For RNA extraction, bead beating $(0.1 \mathrm{~mm}$ zirconia/ silica beads, Biospec Products, USA) was applied with $10 \%$ SDS for lysis of the biofilm cells. The cells were then lysed in a beadbeater for 60 seconds at 4,600 rpm, then centrifuged for $3 \mathrm{~min}$ utes at 12,000 rpm and $4{ }^{\circ} \mathrm{C}$. The supernatant was collected in a new sterile $2 \mathrm{~mL}$ tube, with RNAiso plus (Cat no. 9108; TaKaRa, Japan) then applied to isolate RNA according to the manufacturer's protocols. Subsequently, reverse transcription (AccuPower RT PreMix; K-2041, Bioneer, Korea) was performed using $10 \mu \mathrm{L}$ of the RNA extract to make cDNA; this cDNA was further used for a real-time reverse transcriptase (RT)-PCR assay in order to quantify the amount of the transcribed spoOA gene.

RT-PCR was conducted and then analyzed using a RotorGene 6000 system (Corbett Research, USA), with SYBR Green, a fluorescent double-stranded DNA (dsDNA)-intercalating dye. Two primers, forward: 5'- GGN RTN CCN GCN CAY ATH AAR GGN TA -3') and reverse: 5' - CAT NGC DAT RAA YTC NSW RTT NGT NGG YTT -3 '), were used to amplify the results by about 
300 bps against the $s p o O A$ gene of Bacillus sp. Sea-3[19]. For RTPCR, individual $20-\mu \mathrm{L}$ reaction mixtures contained 10 pmole of each primer, $2 \mu \mathrm{L}$ of the template DNA and $10 \mu \mathrm{L}$ of the SYBR Green PCR master mix (Cat. no. QT605-5100, SeniMixPlus SYBR; Quantace, Finchley, UK). The thermal cycling reactions consisted of an initial denaturation/enzyme activation step $\left(94^{\circ} \mathrm{C}\right.$, 15 minutes) followed by 40 cycles of denaturation $\left(94^{\circ} \mathrm{C}, 30 \mathrm{sec}-\right.$ onds), primer annealing $\left(55^{\circ} \mathrm{C}, 30\right.$ seconds) and extension $\left(72^{\circ} \mathrm{C}\right.$, 30 seconds); for each cycle, the fluorescence was recorded for the final 5 seconds at $72^{\circ} \mathrm{C}$.

To determine the specificities of the amplified products affected by nonspecific amplification and/or primer dimmer formation, a melting-point analysis was carried out after completion of the amplification; slow heating at $1^{\circ} \mathrm{C}$ per step from $72-95^{\circ} \mathrm{C}$ was performed, while continuously acquiring fluorescence data during the $5 \mathrm{~s}$ hold per step. A standard curve for the RT-PCR assay was created by serially diluting the standard plasmids (about 300 bps-spoOA gene fragment of Bacillus sp. MOLA 87 [Accession no. AM990861]), ranging from $8.8 \times 10^{2}$ to $8.8 \times 10^{7}$ copies. By comparing the threshold cycle $\left(\mathrm{C}_{\mathrm{T}}\right)$ values, the standard curve was then used to calculate the number of both the spoOA genes expressed during biofilm formation and the $s p o O A$ DNA gene in the biofilm cells.

\section{Results}

\subsection{Permeate Flux Performance}

The decline in the permeate flux was determined for both Cases I and II experiments. For Case I, the membrane test unit was cleaned with various detergents and chemical disinfectants before adding the Bacillus sp. as the biofoulant; whereas, for Case II, the same test unit was only circulated with distilled water. The different cleaning methods might not have a significant influence on the development of a biofilm on the membrane surface. However, our focus in this study was on obtaining two comparable biofilms in terms of biofouling characteristics than on the experimental conditions. During crossflow filtration, the permeate flux in both cases gradually decreased, and after 272 and 208 hours, the fluxes declined by 20 and 33\% in Cases I and II, respectively (Fig. 1). A minor permeate flux decline was ob-

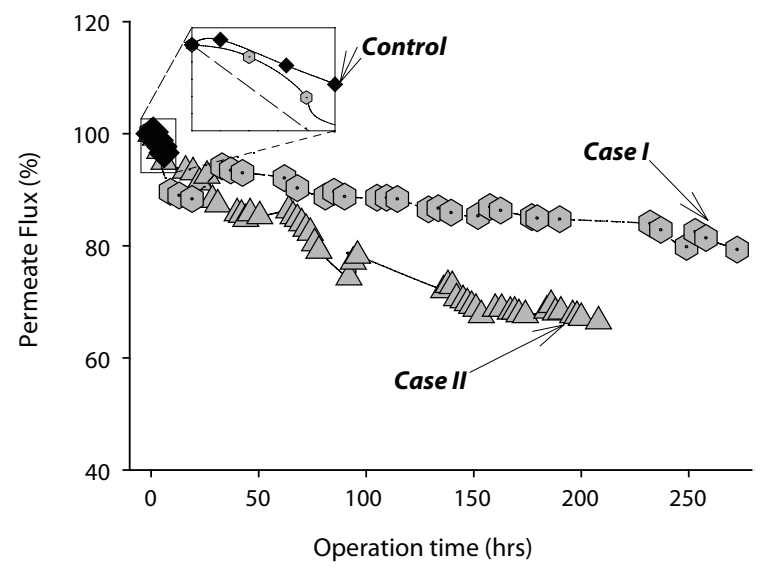

Fig. 1. Decline of the permeate fluxes in Cases I and II due to biofilm formation on the reverse osmosis membranes. served in the control experiment, which contained no Bacillus strain. Note: at the end of the Case II period, a relatively rapid decline of the flux rate was observed compared to Case I.
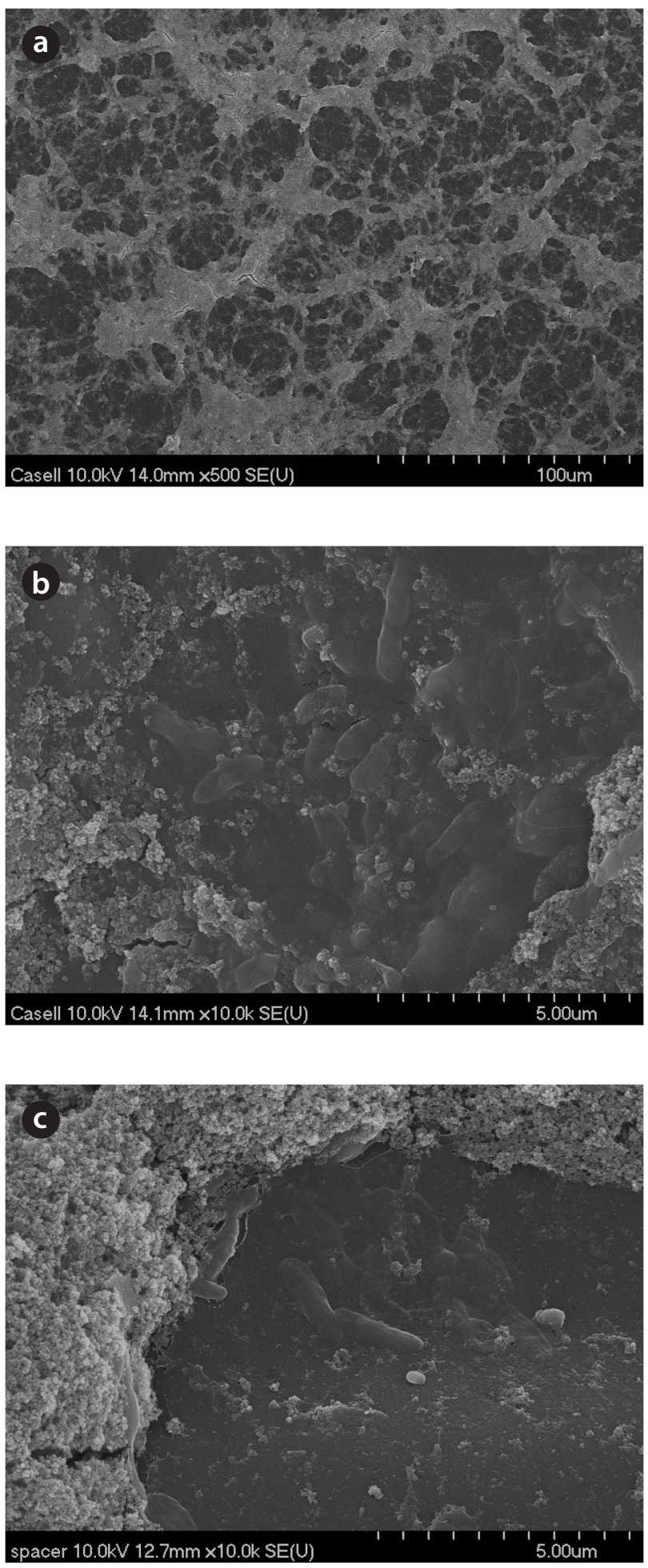

Fig. 2. Scanning electron microscope images of the Case II biofilm. The surface image of the reverse osmosis (RO) membrane at lowermagnification (a), bacteria colonized in the biofilm matrix on the RO membrane (b) and bacteria on the spacer (c). 


\subsection{Bacillus Biofilm Autopsy Formed on RO Membrane}

Fig. 2 presents the SEM images of the membrane surface morphology. The fouling of the membrane in Case II initially appears as in a web-like form at lower magnification (a), although a closer observation of the membrane surface revealed a large amount of bacteria embedded or grown beneath the inorganic aggregates (b). Bacteria attached to the spacer surface used in the assembly of the test unit were also observed (c). However, it was hard to capture the images of bacteria present in the biofilm for Case I (data not shown). The energy-dispersive X-ray (EDX) spectra of the biofilms in Cases I and II indicated the presence of $\mathrm{Na}(1.19 \%), \mathrm{Si}(2.60 \%), \mathrm{S}(0.91 \%), \mathrm{C}(47.46 \%)$ and O $(47.83 \%)$. The composition found from the EDX analysis was relatively constant, with less than $1 \%$ fluctuations.

\subsection{Measurements of Total Count, Viability, Dry Weight, Organic Matters, EPS Protein and EPS Hexose}

The direct fluorescence microscopic counts for enumeration of the total count included both live and dead cells. Based on the results shown in Table 3, the difference in the total counts between the two biofilms was not significant $(p>0.05)$. The viabilities of all the bacteria in the biofilm extracts from Cases I and II were determined using flow cytometry; the percentages of viable cells were about $70 \%$ in both biofilms, but there was no statistical difference $(p>0.05)$. From the results of the total counts and viabilities, it was determined that both the Cases I and II biofilms had similar amounts of biomass.

In both cases, dry weights of $12-13 \mathrm{mg}$ per $140 \mathrm{~cm}^{2}$ of the RO membranes were measured, with the dry masses mainly composed of organic matter, at 11-12 mg per $140 \mathrm{~cm}^{2}$ (90.5-90.6\%). EPS protein and EPS hexose measurements were then carried out by extracting the EPS from each biofilm. Many of the bacterial EPS were found to possess 1, 3- or 1, 4- $\beta$-linked hexose residues [20] and the most common monosaccharides in the EPS were hexose D-glucose, D-galactose and D-mannose, with pentose, hexosamine and glucuronic acids, as well as hexose also found in the EPS from the biofilms. The phenol-sulfuric acid method was used to quantify the carbohydrates, which mainly estimates the concentration of hexose sugars because different sugars have different absorbencies. Thus, the term 'EPS hexose'

Table 3. Measurements of the total counts, viabilities, dry weights, organic matters, EPS protein and EPS hexose in the Cases I and II biofilms. Data values indicate the mean of triplicate measurements (error bar, $1 \times \mathrm{SD}$ )

\begin{tabular}{lcc}
\hline & Case I & Case II \\
\hline Total count $\left(\right.$ cells $\left./ \mathrm{cm}^{2}\right)$ & $1.65 \mathrm{E}+07(2.34 \mathrm{E}+06)$ & $1.32 \mathrm{E}+07(2.31 \mathrm{E}+6)$ \\
Viability $(\%)$ & $69.5(5.8)$ & $68.04(3.67)$ \\
Dry weight $\left(\mathrm{mg} / 140 \mathrm{~cm}^{2}\right)$ & $12.37(0.81)$ & $13.53(1.46)$ \\
Organic matter $\left(\mathrm{mg} / 140 \mathrm{~cm}^{2}\right)$ & 11.2 & $12.25(1.48)$ \\
EPS hexose $\left(\mathrm{mg} / 140 \mathrm{~cm}^{2}\right)$ & $0.78(0.09)$ & $8.13(0.73)$ \\
EPS protein $\left(\mathrm{mg} / 140 \mathrm{~cm}^{2}\right)$ & $2.16(0.11)$ & $2.27(0.18)$ \\
\hline
\end{tabular}

Only the EPS hexose in the two biofilms showed a statistically significant value (at $p<0.05$ ); whereas, $p$ values greater than 0.05 , as calculated in the other tests, were not considered to show statistically significant differences between the two biofilms $(n=3)$. EPS: extracellular polymeric substances. was used rather than EPS carbohydrate or EPS polysaccharide. For Case I, 17.5 and 6.3\% EPS proteins and EPS hexose were observed; whereas, 16.7 and $60 \%$, respectively, were found in Case II (Table 3). These results showed that although similar amounts of EPS protein were obtained in both cases $(p>0.05)$, the EPS hexose of the two biofilms showed statistically different values $(p<0.05)$. The amount of EPS hexose was observed to be about three times higher in the Case II biofilm than in that of Case I.

In typical biofilms, more than $50 \%$ of the total organic matters are composed of dried deposits, and the approximate $90 \%$ organic content indicated a severe case of biofouling. For example, organic matters have been reported to account for $30-55 \%$ of the dry mass [21], with the percentage of organic matters of up to $94 \%$ [22]. Our results showed similar dry weight, organic matter and total cell count values.

\subsection{Measurement of spoOA Gene Expressions}

In this study, an observation of the spoOA gene expression was conducted to verify if the extent of spoOA gene expression in the Bacillus sp. biofilm had relevance to biofouling. It was hypothesized that the $s p o O A$ gene was more actively expressed in the fouled than the less fouled membrane.

The results in Fig. 3a show the relative spoOA gene expressions of the biofilm extracts for Cases I and II. As a result, the level of spoOA gene expression was found to be much higher in Case II than in Case I $(p<0.05)$. However, the number of culturable Bacillus sp. Sea-3 isolates was significantly higher in Case I than in Case II $(p<0.05)$. This result suggested that different expression levels of the $s p o O A$ gene in the Case I and Case II biofilms were not relevant to the number of Bacillus sp. Sea-3. Also, the activity of the spoOA gene, not the number of Bacillus cells, had more positive correlations with membrane biofouling, as the Case II was more fouled with biofilm than the Case I.

Selection of the $s p o O A$ gene in this study was well founded. Diverse genes are known to genetically control of Bacillus biofilms. For example, yve and eps operons are involved in the production of EPS and TasA, with the gene product of tasA being the main protein component of the Bacillus biofilm [23]. SpoOA is also a well known regulatory protein, which is required for the initial stages of biofilm development. Incidentally, the SpoOA is synthesized from a sporulation transcription factor gene, $s p o O A$.
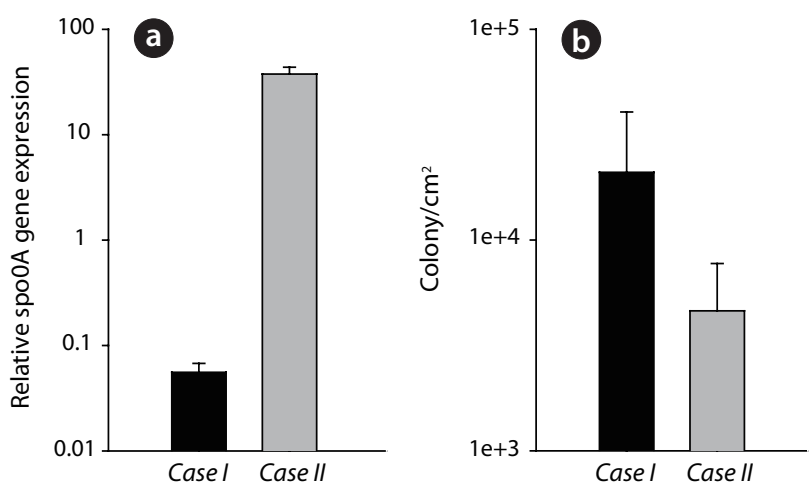

Fig. 3. (a) Measurement of the relative spoOA gene expression and (b) culturable Bacillus $s p$. Sea-3 counts for the Cases I and II biofilms. Each value represents the mean of three independent assays; the error bars show $1 \times \operatorname{SD}(n=3)$. 


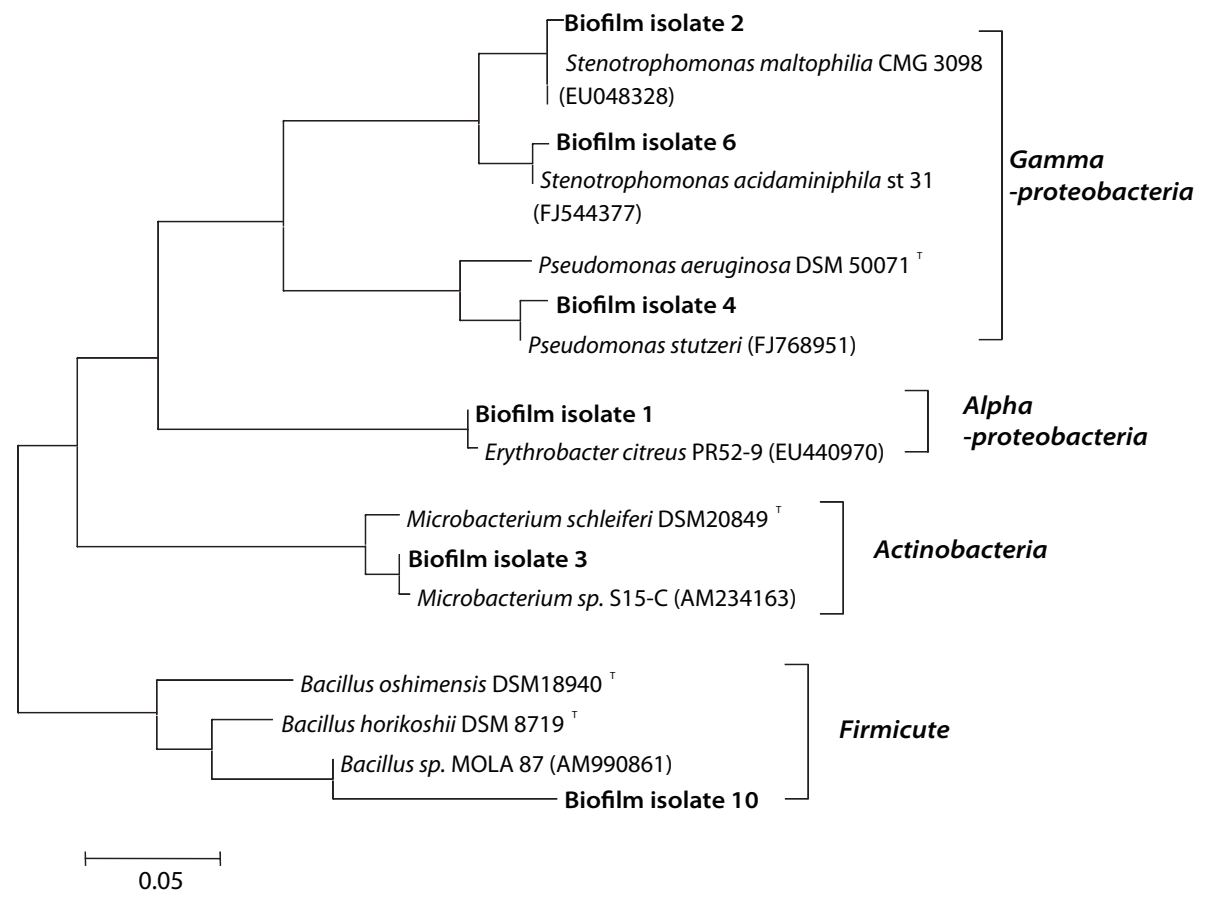

Fig. 4. Bacillus and other culturable bacteria present in the Case II biofilm. The biofilm isolates were identified using 16S rRNA gene sequencing and a basic local alignment search tool (BLAST) search.

The expression of this gene is required for both sporulation and biofilm construction. It is also known that spoOA gene expression is involved in cell-cell communication, because a mutant of the Bacillus strain defective in the synthesis of SpoOA protein could not form multi cellular structures in biofilms. Secondly, SpoOA negatively controls abrB activity, which has a role in suppressing the relevant genes involved in intercellular adhesion [14]. Third, the synthesis of TasA protein requires the transcription factor SpoOA.

In terms of the relationship between the bacterial mass of the biofilm and biofouling, the mass of an individual bacterium did not give rise to significant biofouling. For this reason, it has proved quite difficult to control biofouling by reducing the number of microorganisms in water due to the unclear link between microbial communities and the membrane [24]. However, the activation of genes of interest, which indicate a functional inclination to form the biofilm on an RO membrane, had a much more significant effect on biofouling. Studies to determine the gene expression patterns in bacterial biofilms have recently increased. For instance, biofilm genes essential in the initial step of adhesion may not be activated in biofilms formed later and in those with more complex structures [25]; also, EPS synthesisrelated genes increase during biofilm formation; whereas, pili or flagella-related genes decrease [17].

\subsection{Bacillus and Other Culturable Bacteria in Case II Biofilm}

When each biofilm extract was cultured on marine agar, a yellow colony, revealing Bacillus $s p$. Sea-3, was only grown from in the Case I biofilm. However, other colonies were grown with a yellow-colored colony in the Case II biofilm. Identification of other bacteria was performed using $16 \mathrm{~S}$ rRNA gene sequencing and based on a comparison with the GenBank database using a basic local alignment search tool (BLAST) search. The isolates screened in this study had similarities ranging from 99 to $100 \%$.

As a result of the 16S rRNA sequencing, with the exception of the Firmicute group containing Bacillus sp., three different phylum-based microbial groups were observed (Fig. 4). Generally, Gamma-proteobacteria, Alpha-proteobacteria, and Actino-bacteria have been identified as emerging groups that comprise the biofilms formed on RO membranes, and the abundances of proteobacteria in biofilms formed on the membrane systems and in the feed water sources are also well known [26]. In detail, genetically similar bacteria were observed, such as Stenotrophomonas sp., Pseudomonas sp., Erythrobacter $s p$. and Microbacterium sp. The bacteria Pseudomonas sp. and Microbacterium sp. are commonly found in seawater, and have been extensively studied for their effects on biofilms and membrane filtration (e.g. in situ biofilm monitoring with attenuated total reflectance-Fourier transform infrared (ATR-FTIR), evaluation of the efficiency of biocides against biofilms, bacteria monitoring of the biofilm structure).

\section{Conclusions}

Biofouling measurements of two different Bacillus sp. biofilms were conducted to gain an understanding of the biofouling characteristics induced by a sporogenic Bacillus strain found in seawater. For the study, the Bacillus strain was isolated from the seawater intake to an $\mathrm{RO}$ desalination process, with two distinct sets of experiments performed to form a biofilm on an RO membrane using a lab-scale test unit under high pressure. Based on a series of experiments, the processes of biofilm formation between Case I and Case II were found to be almost the same. 
However, in Case I the membrane test unit was disinfected with various detergents and chemicals; whereas, the same test unit was only circulated with distilled water in Case II.

In Case II, more biofilm fouling was observed than in Case I due to the higher amount of EPS hexose and larger decline of the permeate flux in Case II. From the results, no significant differences were observed in the total counts, dry weights, total organic matters and amounts of EPS protein between the two biofilms. However, significant differences in the EPS hexose, spoOA gene expression and number of culturable Bacillus sp. Sea-3 were observed. Higher $s p o O A$ gene expression and less number of Bacillus sp. Sea-3 were observed in the more fouled Case II biofilm. This implies that the activity of the spoOA gene was not correlated with the number of Bacillus cells, but was well correlated with membrane biofouling.

It was noted in this study that the extent of spoOA gene expression, as a biofouling indicator, was limited to the biofilm mainly induced by sporogenic Bacillus strains, since the spoOA gene was only found in Bacillus. In particular; therefore, the genes of interest in the SWRO system can be applied as targets in the diagnosis of biofouling. Finally, the bacterial species or strains showing a significant expression pattern of a particular gene are suggested as target microorganisms for the development of a monitoring system for RO processes.

\section{Acknowledgements}

This research was supported by a grant (07SeaHeroA01-01) from the Plant Technology Advancement Program, funded by the Ministry of Land, Transport and Maritime Affairs of the Korean Government.

\section{References}

1. Al-Ahmad M, Abdul Aleem FA, Mutiri A, Ubaisy A. Biofuoling in RO membrane systems Part 1: Fundamentals and control. Desalination 2000;132:173-179.

2. Paul DH. Reverse osmosis: scaling, fouling and chemical attack. Desal. Water Reuse 1991;1:8-11.

3. Khedr MG. Membrane fouling problems in reverse osmosis desalination applications. Desal. Water Reuse 2000;10:8-17.

4. Jang N, Shon H, Ren X, Vigneswaran S, Kim IS. Characteristics of bio-foulants in the membrane bioreactor. Desalination 2006;200:201-202.

5. Ridgway HF, Kelly A, Justice C, Olson BH. Microbial fouling of reverse-osmosis membranes used in advanced wastewater treatment technology: Chemical, bacteriological, and ultrastructural analyses. Appl. Environ. Microbiol. 1983;45:1066-1084.

6. Baker JS, Dudley LY. Biofouling in membrane systems - a review. Desalination 1998;118:81-90.

7. Sadr Ghayeni SB, Beatson PJ, Schneider RP, Fane AG. Adhesion of waste water bacteria to reverse osmosis membranes. J. Membr. Sci. 1998;138:29-42.

8. Flemming HC, Schaule G. Biofouling on membranes - A microbiological approach. Desalination 1988;70:95-119.

9. Bereschenko LA, Heilig GHJ, Nederlof MM, Van Loosdrecht MCM, Stams AJM, Euverink GJW. Molecular characterization of the bacterial communities in the different compartments of a full-scale reverse-osmosis water purification plant. Appl. Environ. Microbiol. 2008;74:5297-5304.

10. Chen CL, Liu WT, Chong ML, et al. Community structure of microbial biofilms associated with membrane-based water purification processes as revealed using a polyphasic approach. Appl. Microbiol. Biotechnol. 2004;63:466-473.

11. Ivnitsky H, Katz I, Minz D, et al. Bacterial community composition and structure of biofilms developing on nanofiltration membranes applied to wastewater treatment. Water Res. 2007;41:3924-3935.

12. Lee J, Kim SM, Jung JY, Oh BS, Kim IS, Hong SK. Analysis of total bacteria, enteric members of $\gamma$-proteobacteria and microbial communities in seawater as indirect indicators of quantifying biofouling. Environ. Eng. Res. 2009;14:19-25.

13. Jung JY, Lee J, Kim S, Kim IS. Characteristics on the adhesion and the high pressure resistance of bacteria in biofilm of SWRO process. J. of KSEE 2009;31:51-57.

14. Hamon MA, Lazazzera BA. The sporulation transcription factor Spo0A is required for biofilm development in Bacillus subtilis. Mol. Microbiol. 2001;42:1199-1209.

15. Kim S, Cho D, Lee MS, Oh BS, Kim JH, Kim IS. SEAHERO R\&D program and key strategies for the scale-up of a seawater reverse osmosis (SWRO) system. Desalination 2009;238:1-9.

16. Jochem FJ. Morphology and DNA content of bacterioplankton in the northern Gulf of Mexico: Analysis by epifluorescence microscopy and flow cytometry. Aquat. Microb. Ecol. 2001;25:179-194.

17. Herzberg M, Elimelech M. Physiology and genetic traits of reverse osmosis membrane biofilms: A case study with Pseudomonas aeruginosa. ISME Journal 2008;2:180-194.

18. Bin Z, Baosheng S, Min J, Taishi G, Zhenghong G. Extraction and analysis of extracellular polymeric substances in membrane fouling in submerged MBR. Desalination 2008;227:286-294.

19. Brill JA, Wiegel J. Differentiation between spore-forming and asporogenic bacteria using a PCR and Southern hybridization based method. J. Microbiol. Methods 1997;31:29-36.

20. Sutherland IW. Biofilm exopolysaccharides: a strong and sticky framework. Microbiology 2001;147:3-9.

21. Schneider RP, Ferreira LM, Binder P, et al. Dynamics of organic carbon and of bacterial populations in a conventional pretreatment train of a reverse osmosis unit experiencing severe biofouling. J. Membr. Sci. 2005;266:18-29.

22. Hu JY, Song LF, Ong SL, Phua ET, Ng WJ. Biofiltration pretreatment for reverse osmosis (RO) membrane in a water reclamation system. Chemosphere 2005;59:127-133.

23. Branda SS, Chu F, Kearns DB, Losick R, Kolter R. A major protein component of the Bacillus subtilis biofilm matrix. Mol. Microbiol. 2006;59:1229-1238.

24. Flemming HC. Reverse osmosis membrane biofouling. Exp. Therm Fluid Sci. 1997;14:382-391.

25. Beloin C, Ghigo JM. Finding gene-expression patterns in bacterial biofilms. Trends Microbiol. 2005;13:16-19.

26. Lawrence JR, Swerhone GDW, Leppard GG, et al. Scanning transmission X-ray, laser scanning, and transmission electron microscopy mapping of the exopolymeric matrix of microbial biofilms. Appl. Environ. Microbiol. 2003;69:55435554. 